\title{
PENGARUH PEMBERIAN DOSIS PUPUK BIOURIN TERHADAP PERTUMBUHAN DAN HASIL TANAMAN SAWI PUTIH (Brassica chinensis L.)
}

\author{
Albertus Agung Neno \\ PT. Karya Mas Adinusantara, Jl. Cikini Raya No.12 \& 14, RT.13/RW.5, Cikini, \\ Kecamatan Menteng, Kota Jakarta Pusat, Daerah Khusus Ibukota Jakarta 10330 \\ agungneno@gmail.com
}

\begin{abstract}
The Effect Of Giving Biourin Fertilizer Dosage On Plant Growth And Results. Chinese Cabbage. This study aims to determine the effect of Biourine fertilizer dosage on the growth and production of chicory and to determine the optimum dose of Biourine fertilizer in increasing growth and yield of chicory is BU0 0, liter/ha (control) BU1, 4000 liter/ha or equivalent to 2 ltr/plot BU2, 8000 liters/ha or equivalent to $4 \mathrm{ltr} /$ plot BU3,12,000 liters / ha or equivalent to 6 liters/plot BU4.16,000 liters/ha or the equivalent of $8 \mathrm{ltr} /$ plot. The observation variable of plant height growth was $0.94 \%$, the total average number of leaves was $3.48 \%$, the total average crop diameter was $2.51 \%$, the total average fresh weight of $\operatorname{ton}^{-1}$ stover was $2.23 \%$, the total average fresh weight of stover $\mathrm{ha}^{-1}$ was $2.23 \%$. The results of this study indicate that dosing of biourine fertilizer can increase the percentage of growth and yield of chicory (Brassica chinensis L), namely plant height of $0.94 \%$, number of leaves by $3.48 \%$, crop diameter of $2.51 \%$, fresh weight. Cropping was $2.23 \%$ and fresh weight per hectare was $2.23 \%$. The optimum dose of biourine fertilizer for the best chicory plants in increasing the growth of chicory is 16,000 liters/ha which gives a plant height growth of $24.47 \mathrm{~cm}$, number of leaves is 14.35 , crop diameter is $13.95 \mathrm{~cm}$, fresh weight of stover. Plants amounted to 486.25 grams/plant and 475.40 grams/plant, the fresh weight of plant stover per hectare was 19.45 tons/ha and 19.02 tons/ha.
\end{abstract}

Keywords: Biourin, Chinese cabbage, Fertilizer dosage

\section{PENDAHULUAN}

Sawi putih (Brassica chinensis L.) termasuk ke dalam kelompok tanaman sayuran daun yang sudah sangat populer di masyarakat. Jenis sayuran ini mengandung zat-zat gizi lengkap yang memenuhi syarat untuk kebutuhan gizi masyarakat. Sawi putih sebagai bahan makanan sayuran bisa di konsumsi dalam bentuk mentah sebagai lalapan maupun dalam bentuk olahan dalam berbagai macam masakan. Selain berguna untuk bahan makanan, sawi putih juga berguna untuk pengobatan terapi berbagai macam penyakit. Sehingga dengan demikian, sawi putih 
memiliki peranan yang sangat penting di dalam menunjang kesehatan masyarakat (Cahyono, 2000).

Produksi sawi putih di Indonesia tahun 2013 dengan luas panen 62.951 ha mempunyai tingkat produksi mencapai 635.728 ton, dengan produktivitas 10,10 ton/ha (BPS, 2014). Sedangkan tahun 2014, produksi sawi putih di Indonesia dengan luas panen 60.804 ha mempunyai tingkat produksi mencapai 602.468 ton, denagan produktivitas 9,91 ton/ha (BPS, 2014). Hal ini menunjukkan bahwa produksi serta produktivitas sawi putih di Indonesia pada tahun 2014 mengalami penurunan dibandingkan pada tahun 2013.

Produksi sawi putih di Kabupaten Ende tahun 2013 dengan luas panen 19.65 ha mempunyai tingkat produksi mencapai 2,8 ton, dengan produktivitas 14,91 kw/ha (Dinas Pertanian Kabupaten Ende, 2014). Sedangkan tahun 2014, produksi sawi putih di Kabupaten Ende dengan luas panen 19,12 ha mempunyai tingkat produksi mencapai 28,26 ton, dengan produktivitas 14,13kw/ha (Dinas Pertanian Kabupaten Ende. 2014). Hal ini menunjukkan bahwa produksi serta produktivitas sawi putih di Kabupaten Ende pada tahun 2014 mengalami penurunan dibandingkan pada tahun
2013 (Dinas Pertanian Kabupaten Ende. 2014). Berdasarkan data di atas, bahwa produktivitas sawi putih di Kabupaten Ende masih jauh lebih rendah dibandingkan dengan produktivitas sawi putih pada tingkat Nasional.

Hal ini disebabkan oleh banyaknya permasalahan yang terjadi dalam kegiatan budidaya sawi putih dimulai dari pengolahan lahan hingga panen.Salah satu masalah yang paling sering dihadapi oleh petani adalah pemupukan. Masyarakat petani di Kabupaten Ende mengusahakan sawi putih dengan tidak memperhatikan metode pemupukan yag baik dan benar. Pemupukkan dilakukan agar dapat memenuhi kebutuhan hara yang kurang atau tidak sesuai sehingga dapat meningkatakan produksi. Jika tanaman tidak mendapatkan unsur hara yang cukup untuk pertumbuhannya, maka pertumbuhannya juga terganggu (Harjadi, 1993; Gardner et al, 2008).

Penggunaan pupuk yang salah dapat menyebabkan proses produksi yang tidak efisien. Kesalahan penggunaan pupuk dapat mengakibatkan biaya produksi meningkat tetapi hasil yang diperoleh tidak seperti yang diharapkan. Selain itu penggunaan pupuk kimia dalam jangka panjang 
Neno: Pengaruh pemberian dosis pupuk biourin terhadap pertumbuhan dan hasil tanaman padi

secara terus menerus dan tidak terkendali akan berdampak buruk pada kesuburan tanah dan lingkungan di sekitar daerah pertanian (Hardjowigeno, 2003; Hanafiah 2007; Islmai dan Utomo, 2011).

Salah satu cara yang dilakukan untuk mengatasi permasalahan di atas adalah dengan menerapkan pertanian organik untuk mencegah semakin merosotnya kesuburan tanah. Faktor pendukung penting dalam pertanian organik adalah pupuk organik. Pupuk organik padat lebih banyak dimanfaatkan pada usahatani, sedangkan limbah cair (urine) masih belum banyak dimanfaatkan (Adijaya, 2006).

Urin sapi dapat dimanfaatkan sebagai pupuk organik cair melalui proses fermentasi dengan melibatkan peran mikroorganisme, sehingga dapat menjadi produk pertanian yang lebih bermanfaat yang biasa disebut dengan Biourine (Hadinata, 2008 dalam Sutari, 2010). Biourine merupakan salah satu alternatif untuk meningkatkan ketersediaan, kecukupan, dan efisiensi serapan hara bagi tanaman yang mengandung mikroorganisme sehingga dapat mengurangi penggunaan pupuk anorganik $(\mathrm{N}, \mathrm{P}, \mathrm{K})$ dan meningkatkan hasil tanaman secara maksimal.
Hal ini dikarenakan biourine banyak mengandung unsur hara yang dibutuhkan oleh tanaman dalam proses pertumbuhan. Biourine memiliki banyak kandungan hara baik makro maupun mikro yang dibutuhkan oleh tanaman. Menurut Lingga (1991), urine sangat baik digunakan sebagai pupuk organik cair karena memiliki kandungan hara yang lengkap. Meskipun fluktuatif bergantung pada lokasi dan sumbernya, kandungan $\mathrm{N}$ pada Biourine sekitar 1,4 hingga 2,2\%, phosphor (P) yaitu 0,6 hingga $0,7 \%$ dan kalium (K) yaitu 1,6 hingga $2,1 \%$.

Hasil penelitian Rizki et al. (2014) melaporkan bahwa pemberian biourine dengan dosis 8000 liter/ha dapat meningkatkan pertumbuhan tanaman sawi hijau yang optimal yaitu meningkatkan rata-rata tinggi tanaman sebesar 47,15 cm, rata-rata jumlah daun sebanyak 12,65 helai, rata-rata luas daun sebesar $304,25 \mathrm{~cm}^{2}$, rata-rata bobot pertanaman 154,45 gram. Melihat dengan fakta yang ada diatas, maka penulis ingin melakukan penelitian terhadap" Pengaruh Pemberian Dosis Pupuk Biourine terhadap ertumbuhan dan hasil tanaman sawi putih (Brassica chinnensis L).penelitian ini bertujuan untuk Mengetahui pengaruh pemberian 
dosis Biourine terhadap pertumbuhan dan hasil tanaman sawi putih dan memberikan dosis optimum pupuk biourine yang dapat memberikanpertumbuhan dan hasil sawi putih yang optimal.

\section{METODE PENELITIAN}

Tempat dan Waktu

Percobaan ini dilakukan di kebun contoh Fakultas Pertanian Universitas Flores di Kelurahan Lokoboko, Kecamatan Ndona, Kabupaten Ende, denganketinggian tempat $500 \mathrm{~m} \mathrm{dpl}$. Perconaan ini dilakukan pada bulan Februari hingga Mei 2015. Kondisi tanah memiliki pH 5,8-7,2 C-Organik tergolong rendah dengan nilai $1,42 \%, \mathrm{~N}$ total tergolong rendah dengan nilai 0,15\%, P-tersedia tergolong sedang dengan nilai 19,25 $\mathrm{mg}, \quad \mathrm{K}$-tersedia tergolong tinggi dengan nilai 246,39 me/100g dan memiliki tekstur Tanah lempung berpasir. Penelitian ini dilakukan pada bulan April sampai Juli 2016.

\section{Bahan dan Alat}

Bahan yang di gunakan dalam penelitian adalah: Benih sawi putih, Pupuk biou-urin, tanah. Alat yang digunakan dalam penelitian ini adalah: meteran, tali rofia, cangkul, parang, sekop, ember, selang, gayung, kertas label, papan perlakuan, handsprayer dan alat tulis menulis lainnya dalam mendukung percobaan ini.

\section{Metode Penelitian}

Rancangan yang digunakan dalam percabaan ini adalah rancangan Acak kelompok (RAK) dengan pola factor tunggal yang terdiri dari 5 perlakuan yaitu:

BU0: 0 liter/ ha (control)

BU1: 4000 liter/ha atau setara dengan 2 ltr/petak

BU2: 8000 liter/ha atau setara dengan 4 ltr/petak

BU3: 12.000 liter/ha atau setara dengan $6 \mathrm{ltr} /$ petak

BU4: 16.000 liter/ha atau setara dengan $8 \mathrm{ltr} /$ petak

Masing-masing perlakuan di ulang sebanyak 4 kali. Setiap perlakuan terdiri dari 20 petak percobaan, sehingga terdapat 500 tanaman percobaan. Setiap perlakuan diambil 5 tanaman sampel.

\section{Pelaksanaan Penelitian}

Persiapan Lahan

Pengolahan lahan dilakukan dengan cara mengukur tempat pengamatan yakni: tanah dicangkul menjadi gembur setelah itu dibuat bedengan dengan ukuran Jarak antar bedengan $40 \mathrm{~cm}$ dan jarak antar ulangan $50 \mathrm{~cm}$. dengan luas petak $2,0 \times 2,5 \mathrm{~m}$ yaitu $5,0 \mathrm{~m}^{2}$. 
Neno: Pengaruh pemberian dosis pupuk biourin terhadap pertumbuhan dan hasil tanaman padi

\section{Persemaian}

Sebelum melakukan persemaian, biji sawi putih direndam dalam air yang sudah dicampur dengan fungisida Risolex 50 WP, bertujuan untuk menghindar jamur pada benih saat berkecambah, selanjutnya benih disemaikan pada tempat persemaian (belah bambu). Tanaman siap dipindahkan setelah berumur 10 hari atau terdapat kurang 3 daun.

\section{Penanaman}

Untuk penanaman sawi dilakukan dengan menanam tanaman sawi putih kedalam petak yang sudah disiapkan dengan jarak tanam $40 \times 50 \mathrm{~cm}$. Terlebih dahulu dibuat lubang tanam sedalam 3-5 cm setiap lubang ditanami 1 anakan.

\section{Aplikasi Biourine}

Biourine diberikan pada saat tanaman berumur 0 hst (saat tanam), 10 hst, 20 hst, 30 hst, 40 hst dengan dosis 0 ltr/petak, 2 ltr/petak, 4 ltr/petak, 6 ltr/petak dan 8 ltr/petak. Setiap aplikasi dosis perlakuan dibagi 5 kali aplikasi. Sehingga dosis yang digunakan pada setiap kali aplikasi adalah 0 liter/petak untuk dosis 0 liter/petak. 0,4 liter/petak untuk dosis 2 liter/petak, 0,8 liter/petak untuk dosis 4 liter/petak, 1,2 liter/petak untuk dosis 6 liter/petak dan 1,6 liter/petak untuk dosis 8 liter/petak. Setiap aplikasi dosis perlakuan kemudian dicampur dengan 10 liter air, kemudian diaplikasikan ke tanaman

\section{Pemeliharaan Tanaman}

Pemeliharaan dapat dilakukan dengan menggantikan (menyulam) tanaman yang mati yaitu pada saat tanaman berumur 0-7 hst. Selain itu pemeliharaan tanaman juga dilakukan dengan membersikan gulma yang tumbuh pada lahan percobaan. Penyiraman dilakukan dua kali sehari yaitu pada pagi dan sore hari.

\section{Panen}

Umur panen sawi putih tergantung varietasnya, dapat dipanen setelah berumur 40 hst. Umumnya perhitungan umur panen sawi putih di mulai dari pindah tanam persemaian ke kebun atau dengan ciri-ciri daun paling bawah sudah menguning dan sudah membentuk krop. Hal ini mendapatkan tanaman sawi putih mulai memasuki fase generatif, yaitu tanaman siap dipanen.

\section{Variabel Pengamatan}

1. Variabel Pertumbuhan Variabel pertumbuhan terdiri dari;

a. Tinggi Tanaman

Tinggi tanaman dihitung dengan cara mengukur tinggi tanaman dari permukaan tanah hingga ujung daun tertinggi. Pengukuran tinggi tanaman dilakukan pada saat tanaman berumur 7 hst, 14 hst, 21 hst, 28 dan 35 hst.

b. Jumlah Daun 
Jumlah daun dihitung dengan cara menghitung jumlah daun pada setiap tanaman sampel dalam setiap perlakuan dan setiap ulangan. Jumlah daun dihitung pada saat tanaman berumur 7 hst, 14 hst, 21 hst, 28 dan 35 hst.

2. Variabel Hasil

1. Berat Segar Pertanaman (g)

2. Berat Segar Per Hektar $(\mathrm{Kg} / \mathrm{Ha})$.

3. Diameter Krop

3. Analisis Data

Data analisis pengamatan di analisis dengan sidik ragam sesuai dengan rancangan yang digunakan apabila perlakuan menunjukan pengaruh nyata terhadap variable yang diamati maka dilanjutkan dengan uji BNT taraf 5 \% (Gomez dan Gomez, 1995)

\section{HASIL DAN PEMBAHASAN}

Hasil analisis statistik menunjukan bahwa perlakuan dosis pupuk biourine berpengaruh sangat nyata terhadap variabel pertumbuhan dan hasil tanaman sawi putih. Hal ini ditunjukkan pada Tabel 1.

Tabel 1 Signifikasi pengaruh dosis pupuk biourine terhadap pertumbuhan dan hasil tanaman sawi putih

\begin{tabular}{clc}
\hline No & \multicolumn{1}{c}{ Variabel Pengamatan } & Signifikasi \\
\hline 1 & Tinggi Tanaman 7 Hst & $* *$ \\
2 & Tinggi Tanaman 14 Hst & $* *$ \\
3 & Tinggi Tanaman 21 Hst & $* *$ \\
4 & Tinggi Tanaman 28 Hst & $* *$ \\
5 & Tinggi Tanaman 35 Hst & $* *$ \\
6 & Jumlah Daun Umur 7 Hst & $* *$ \\
7 & Jumlah Daun Umur 14 Hst & $* *$ \\
8 & Jumlah Daun Umur 21 Hst & $* *$ \\
9 & Jumlah Daun Umur 28 Hst & $* *$ \\
10 & Jumlah Daun Umur 35 Hst & $* *$ \\
11 & Diameter krop & $* *$ \\
12 & Berat Segar Pertanaman & $* *$ \\
13 & Berat Segar Perhektar & $* *$ \\
\hline & Keterangan: Hst : Hari Setelah Tanam \\
\end{tabular}


Neno: Pengaruh pemberian dosis pupuk biourin terhadap pertumbuhan dan hasil tanaman padi

\section{Variabel Pertumbuhan}

Berdasarkan hasil analisis sidik ragam menunjukan bahwa pengaruh pemberian pupuk Biourine terhadap pertumbuhan tanaman sawi putih membrikan pengaruh yang sangat nyata terhadap pertumbuhan tinggi tanaman, jumlah daun tanaman sawi putih yang dapat dilihat pada Tabel 2.

Tabel 2. Pengaruh Pemberian pupuk biourine terhadap pertumbuhan tinggi tanaman sawi putih

\begin{tabular}{cccccc}
\hline \multirow{2}{*}{ Perlakuan } & \multicolumn{5}{c}{ Tinggi Tanaman $(\mathbf{c m})$} \\
\cline { 2 - 6 } & $\mathbf{7}$ hst & $\mathbf{1 4} \mathbf{~ h s t}$ & $\mathbf{2 1} \mathbf{~ h s t}$ & $\mathbf{2 8} \mathbf{h s t}$ & $\mathbf{3 5} \mathbf{h s t}$ \\
\hline BU 0 & $7,70 \mathrm{c}$ & $9,90 \mathrm{~b}$ & $13,56 \mathrm{c}$ & $16,74 \mathrm{c}$ & $20,52 \mathrm{c}$ \\
BU 1 & $7,82 \mathrm{~b}$ & $10,19 \mathrm{ab}$ & $13,86 \mathrm{~b}$ & $17,51 \mathrm{~b}$ & $22,79 \mathrm{~b}$ \\
BU 2 & $7,97 \mathrm{a}$ & $10,22 \mathrm{a}$ & $13,95 \mathrm{~b}$ & $17,74 \mathrm{~b}$ & $23,20 \mathrm{~b}$ \\
BU 3 & $7,99 \mathrm{a}$ & $10,25 \mathrm{a}$ & $14,37 \mathrm{a}$ & $18,27 \mathrm{a}$ & $24,24 \mathrm{a}$ \\
BU 4 & $8,02 \mathrm{a}$ & $10,27 \mathrm{a}$ & $14,53 \mathrm{a}$ & $18,40 \mathrm{a}$ & $24,47 \mathrm{a}$ \\
\hline BNT 5 \% & 0,08 & 0,07 & 0,17 & 0,26 & 0,5 \\
\hline
\end{tabular}

Keterangan: Angka-angka yang diikuti oleh huruf-huruf yang sama pada kolom yang sama berarti tidak berbeda nyata pada taraf uji BNT 5\%.

Hasil analisis sidik ragam menunjukkan bahwa pemberian pupuk biourine berpengaruh nyata terhadap pertumbuhan tinggi tanaman sawi putih. Peningkatan pemberian dosis pupuk biourine diikuti pertumbuhan rata-rata total tinggi tanaman sawi putih yaitu dari perlakuan BU 0 ke B1 sebanyak 9,96\%, BU 1 ke BU 2 sebanyak 1,77\%, BU 2 ke BU 3 sebanyak 4,29\%, dan dari BU 3 ke BU 4 sebanyak $0,94 \%$, dengan demikian hipotesis 1 terbukti

Peningkatan total rata-rata tinggi tanaman sawi putih disebabkan efisiensi penyerapan unsur hara yang terkandung dalam pupuk biourin oleh tanaman sawi putih. Semakin banyak unsur hara yang disediakan oleh tanah semakin banyak pula unsur hara yang diserap oleh tanaman sehingga pertumbuhan tanaman menjadi lebih optimal (Jumin, 2008).

Kandungan hara yang tersedia oleh pupuk biourine yaitukandungan $\mathrm{N}$ sekitar 1,4 hingga 2,2\%, phosphor (P) yaitu 0,6 hingga $0,7 \%$ dan kalium (K) yaitu 1,6 hingga $2,1 \%$. Unsur Nitrogen digunakan untuk pertumbuhan tunas dan batang dan daun. Fosfor (P) digunakan untuk merangsang pertumbuhan akar, buah, dan biji. Sementara kalium (K) digunakan untuk meningkatkan ketahanan tanaman terhadap serangan hama dan penyakit (Jumin, 2008). 
Data diatas menjelaskan bahwa dosis pupuk biourine terbaik dalam meningkatkan pertumbuhan tinggi tanaman sawi putih secara optimal adalah pada perlakuan BU 4 yaitu sebesar 24,47 cm dan tidak berbeda nyata dengan BU3 yaitu 24,24, maka dapat disimpulkan bahwa hipotesis 2 ditolak. Hal ini dikarenakan dosis 8.000 liter/ha pupuk biourine mempengaruhi unsur NPK masing-masing unsur $\mathrm{N}$ sebesar160 liter/ha, P sebesar 80 liter/ha dan $\mathrm{K}$ sebesar 40 liter/ha, sedangkan kebutuhan NPK untuk tanaman sawi yaitu N sebesar 300 liter/ha $\mathrm{P}$ sebesar 150 liter/ha dan $\mathrm{K}$ sebesar 75 liter/ha (Rizky et al., 2014), Sehingga tidak dapat memberikan pertumbuhan tinggi tanaman yang optimal, karena unsur hara yang diberikan masih sangat kurang jika dibandingkan dengan kebutuhan hara tanaman sawi putih.

Tabel 3. Pengaruh Pemberian pupuk biourine terhadap pertumbuhan jumlah daun tanaman sawi putih

\begin{tabular}{cccccc}
\hline \multirow{2}{*}{ Perlakuan } & \multicolumn{5}{c}{ jumlah daun (helai) } \\
\cline { 2 - 6 } & $\mathbf{7}$ hst & $\mathbf{1 4} \mathbf{~ h s t}$ & $\mathbf{2 1} \mathbf{~ h s t}$ & $\mathbf{2 8} \mathbf{~ h s t}$ & $\mathbf{3 5} \mathbf{~ h s t}$ \\
\hline BU 0 & $4,00 \mathrm{~d}$ & $6,40 \mathrm{c}$ & $8,35 \mathrm{~d}$ & $11,10 \mathrm{~d}$ & $12,55 \mathrm{~d}$ \\
BU 1 & $4,25 \mathrm{c}$ & $6,60 \mathrm{~b}$ & $9,05 \mathrm{~cd}$ & $11,50 \mathrm{c}$ & $13,05 \mathrm{c}$ \\
BU 2 & $4,30 \mathrm{c}$ & $6,70 \mathrm{~b}$ & $9,35 \mathrm{c}$ & $12,00 \mathrm{~b}$ & $13,15 \mathrm{c}$ \\
BU 3 & $4,45 \mathrm{~b}$ & $7,15 \mathrm{a}$ & $9,70 \mathrm{~b}$ & $12,65 \mathrm{a}$ & $13,85 \mathrm{~b}$ \\
BU 4 & $4,60 \mathrm{a}$ & $7,30 \mathrm{a}$ & $10,05 \mathrm{a}$ & $12,80 \mathrm{a}$ & $14,35 \mathrm{a}$ \\
\hline BNT 5 \% & 0,11 & 0,19 & 0,30 & 0,36 & 0,31
\end{tabular}

Keterangan: Angka-angka yang diikuti oleh huruf-huruf yang sama pada kolom yang sama berarti tidak berbeda nyata pada taraf uji BNT 5\%.

Tabel 3 menunjukkan bahwa pemberian pupuk biourine berpengaruh nyata terhadap pertumbuhan jumlah daun tanaman sawi putih. Peningkatan pemberian dosis pupuk biourine diikuti pertumbuhan rata-rata total jumlah dauntanaman sawi putih yaitu dari perlakuan B0 ke B1 sebanyak 3,83\%, B1 ke B2 sebanyak 0,76\%, B2 ke B3 sebanyak 5,05\%, dan dari B3 ke B4 sebanyak 3,48\%, dengan demikian hipotesis 1 terbukti.

Peningkatan pemberian pupuk biourine mampu meningkatkan pertumbuhan tanaman sawi putih yaitu dapat meningkatkan pertumbuhan jumlah daun tanaman sawi putih.Peningkatan pertumbuhan jumlah daun tanaman sawi putih dikarenakan unsur hara yang terkandung dalam pupuk biourine semakin banyak yang 
Neno: Pengaruh pemberian dosis pupuk biourin terhadap pertumbuhan dan hasil tanaman padi

digunakan secara optimal oleh tanaman dalam proses pertumbuhan tanaman. Menurut Sutari (2010), biourine sangat baik digunakan sebagai pupuk organik cair karena memiliki kandungan hara yang lengkap. Meskipun fluktuatif bergantung pada lokasi dan sumbernya, kandungan $\mathrm{N}$ pada Biourine sekitar 1,4 hingga 2,2\%, phosphor (P) yaitu 0,6 hingga $0,7 \%$ dan kalium (K) yaitu 1,6 hingga $2,1 \%$. Urin sapi mengandung zat pengatur tumbuh diantaranya Indole Acetic Acid (IAA). IAA merupakan senyawa yang berasal dari golongan auksin. IAA yang terkandung dalam urin sapi memberikan pengaruh positif terhadap pertumbuhan vegetatif tanaman.

Ketersediaan unsur hara pada tanah mempengaruhi pertumbuhan tanaman seperti jumlah daun. Kondisi ini disebabkan karena pembentukan sel-sel baru dalam suatu tanaman sangat erat hubungannya dengan ketersediaan hara pada tanah. Hal ini sejalan dengan pendapat Foth (1994), penetapan konsentrasi dan dosis dalam pemupukan sangat penting dilakukan karena akan berpengaruh tidak baik pada pertumbuhan jika tidak sesuai kebutuhan tanaman. Proses pembentukan daun tidak terlepas dari peranan unsur hara seperti nitrogen dan fosfat yang terdapat pada medium tanah dan dalam kondisi tersedia bagi tanaman. Nyakpa (1988) menyatakan bahwa $\mathrm{N}$ dan $\mathrm{P}$ berperan dalam pembentukan sel-sel baru dan komponen utama penyusun senyawa organik dalam tanaman seperti asam amino, asam nukleat, klorofil, ADP dan ATP.

Data di atas juga menjelaskan bahwa peningkatan total rata-rata pertumbuhan jumlah daun tanaman sawi putih terbaik dari semua variabel pertumbuhan tanaman yaitu pada dosis 16.000 liter/ha atau pada perlakuan BU 4 yaitu sebesar 14,35 helai daun, sehingga diasumsikan bahwa hipotesis 2 tidak diterima. Hal ini dikarenakan dosis 8.000 liter/ha pupuk biourine hanya mampu mempengaruhi unsur NPK masingmasing unsur $\mathrm{N}$ sebesar 160 liter/ha, $\mathrm{P}$ sebesar 80 liter/ha dan $\mathrm{K}$ sebesar 40 liter/ha Sedangkan kebutuhan NPK untuk tanaman sawi putih yaitu $\mathrm{N}$ sebesar 300 liter/ha P sebesar 150 liter/ha dan K sebesar 75 liter/ha (Rizky et al., 2014), Sehingga tidak dapat memberikan pertumbuhan jumlah daun tanaman yang optimal, karena unsur hara yang diberikan masih sangat kurang jika dibandingkan dengan kebutuhan hara tanaman sawi putih. 


\section{Variabel Hasil}

Hasil analisis sidik ragam menunjukkan bahwa pemberian pupuk biourine memberikan pengaruh sangat nyata terhadap peningkatan rata-rata total hasil tanaman sawi putih yang meliputi peningkatan diameter krop, berat brangkasan segar pertanaman dan berat brangkasan segar perhektar, seperti yang disajikan dalam Tabel 4.

Tabel 4. Pengaruh pemberian pupuk biourine terhadap diameter krop, berat segar brangkasan tanaman, dan berat segar brangkasan perhektar tanaman sawi putih

\begin{tabular}{cccc}
\hline Perlakuan & $\begin{array}{c}\text { Diameter } \\
\text { Krop }(\mathbf{C m})\end{array}$ & $\begin{array}{c}\text { Berat Segar Pertanaman } \\
\text { (gram) }\end{array}$ & $\begin{array}{c}\text { Berat Segar } \\
\text { Perhektar }(\mathbf{k g} / \mathbf{h a})\end{array}$ \\
\hline BU 0 & $12,35 \mathrm{~d}$ & $399,95 \mathrm{c}$ & $16,00 \mathrm{c}$ \\
BU 1 & $12,95 \mathrm{c}$ & $438,70 \mathrm{~b}$ & $17,55 \mathrm{~b}$ \\
BU 2 & $13,10 \mathrm{c}$ & $445,45 \mathrm{~b}$ & $17,82 \mathrm{~b}$ \\
BU 3 & $13,60 \mathrm{~b}$ & $475,40 \mathrm{a}$ & $19,02 \mathrm{a}$ \\
BU 4 & $13,95 \mathrm{a}$ & $486,25 \mathrm{a}$ & $19,45 \mathrm{a}$ \\
\hline BNT 5 \% & 0,27 & 13,34 & 0,53
\end{tabular}

Keterangan: Angka-angka yang diikuti oleh huruf-huruf yang sama pada kolom yang sama berarti tidak berbeda nyata pada taraf uji BNT 5\%.

Hasil analisis sidik ragam diakibatkan peningkatan pemberian menunjukkan bahwa pemberian pupuk dosis biourine yaitu peningkatan ratabiourine memberikan pengaruh sangat nyata terhadap peningkatan rata-rata total hasil tanaman sawi putih yang meliputi peningkatan diameter krop, berat brangkasan segar pertanaman dan berat brangkasan segar perhektar.

Peningkatan rata-rata totaldiameter krop yang diakibatkan peningkatan pemberian dosis biourine yaitu peningkatan rata-rata total dari perlakuan B0 ke B1 sebesar 4,63\%, dari B1 ke B2 sebesar 1,15 \%, dari B2 ke B3 sebesar 3,68 \% dan dari B3 ke B4 sebesar $2,51 \%$. Peningkatan rata-rata total berat segar brangkasan tanaman yang rata total dari perlakuan B0 ke B1 sebesar $8,83 \%$, dari B1 ke B2 sebesar 1,52 \%, dari B2 ke B3 sebesar 6,30\% dan dari B3 ke B4 sebesar 2,23\%. Peningkatan rata-rata total berat segar brangkasan tanaman perhektar yang diakibatkan peningkatan pemberian dosis biourine yaitu peningkatan ratarata total dari perlakuan B0 ke B1 sebesar 8,83\%, dari B1 ke B2 sebesar 1,52 \%, dari B2 ke B3 sebesar 6,30\% dan dari B3 ke B4 sebesar 2,23\%.

Dari data diatas dapat disimpulkan bahwa pemberian dosis pupuk biourine mampu meningkatkan hasil produksi 
Neno: Pengaruh pemberian dosis pupuk biourin terhadap pertumbuhan dan hasil tanaman padi

tanaman sawi putih sehingga dapat disimpulkan bahwa hipotesis 1 diterima. Hal ini dikarenakan pemberian pupuk biourine mampu meningkatkan total rata-rata hasil produksi tanaman sawi putih yaitu mampu meningkatkan ratarata total diameter krop, meningkatkan rata-rata total berat segar pertanaman dan mampu meningkatkan rata-rata total berat segar tanaman perhektar.

Peningkatan total rata-rata hasil tanaman sawi putih terbaik dari semua variabel produksi yaitu pada dosis 16.000 liter/ha atau pada perlakuan BU 4 meskipun tidak berbeda nyata terhadap perlakuan BU 3sehingga diasumsikan bahwa hipotesis 2 yaitu BU 2 tidak diterima. Hal ini disebabkan pemberian pupuk biourine lebih mampu meningkatkan rata-rata total diameter krop pada perlakuan BU 4 yaitu sebesar $13,95 \mathrm{~cm}$ dibanding $13,10 \mathrm{~cm}$ pada perlakuan BU 2. Selain itu pemberian pupuk biourine lebih mampu meningkatkan rata-rata total berat segar brangkasan tanaman pada perlakuan BU 4 sebesar 486,25 gram/tanaman dan 475,40 gram/tanaman pada BU 3 dibanding 445,45 gram/tanaman pada perlakuan BU 2. Pemberian pupuk bourine pada perlakuan BU 4 dan BU 3 juga lebih mampu memberikan rata-rata total berat brangkasn tanaman per hektar yaitu sebesar 19,45 ton/ha dan 19,02 ton perhektar dibanding perlakuan BU 2 yaitu sebesar 17,82 ton/hektar. Hal ini berkaitan dosis perlakuan BU 2 (8.000 liter/ha) pupuk biourine yang hanya mampumempengaruhiketersediaan unsur NPK untuk tanaman sawi putih masingmasing unsur $\mathrm{N}$ sebesar 160 liter/ha, $\mathrm{P}$ sebesar 80 liter/ha dan $\mathrm{K}$ sebesar 40 liter/ha Sedangkan kebutuhan NPK untuk tanaman sawi putih yaitu $\mathrm{N}$ sebesar 300 liter/ha $\mathrm{P}$ sebesar 150 liter/ha dan K sebesar 75 liter/ha (Risky et al., 2014), Sehingga tidak memberikan produksi tanaman sawi putih yang optimal, karena unsur hara yang diberikan dalam proses pertumbuhannya masih sangat kurang jika dibandingkan dengan kebutuhan hara tanaman sawi putih jika dibandingkan dengan potensi produksi yang ada pada deskripsi varietas, maka masih memungkinkan dapat dilakukan upaya peningkatan produksi.

Peningkatan total rata-rata diameter krop, berat segar brangkasan tanaman dan berat segar brangkasan perhektar tanaman sawi putih disebabkan efisiensi penyerapan unsur hara yang terkandung dalam pupuk biourin oleh tanaman sawi putih. 
Semakin banyak unsur hara yang disediakan oleh tanah semakin banyak pula unsur hara yang diserap oleh tanaman sehingga pertumbuhan tanaman menjadi lebih optimal. Penyerapan unsur hara makro oleh tanaman sawi putih yang disediakan oleh pupuk biourin yang meliputi unsur $\mathrm{N}, \mathrm{P}$ dan $\mathrm{K}$ menyebabkan daun tumbuh lebih lebar dan permukaan daun lebih luas untuk proses fotosintesis. Meningkatnya proses fotosintesis menyebabkan pembentukan karbohidrat meningkat pula serta tanaman mengalami peningkatan bobot segar sehingga pembelahan dan pembesaran sel berlangsung lebih cepat.

\section{SIMPULAN}

Dari hasil penelitian yang dilakukan dapat ditarik kesimpulan sebagai berikut:

1. Pemberian pupuk biourine berpengaruh nyata dalam meningkatkan persentase rata-rata pertumbuhan tinggi tanaman sebesar $0,94 \%$, persentase rata-rata jumlah daun sebesar $3,48 \%$, persentase ratarata diameter krop sebesar 2,51\%, persentase rata-rata berat segar brangkasan $\operatorname{ton}^{-1}$ sebesar 2,23\%, persentase rata-rata berat segar brangkasan $\mathrm{ha}^{-1}$ sebesar $2,23 \%$.
2. Dosis optimum pupuk biourine untuk tanaman sawi putih terbaik dalam meningkatkan pertumbuhan tanaman sawi putih adalah 12.000 liter/ha yang memberikan pertumbuhan tinggi tanaman sebesar $24,24 \mathrm{~cm}$, jumlah daun sebesar 13,85 helai, diameter krop sebesar 13,60 cm, berat segar brangkasan tanaman sebesar 475,40 gram/tanaman, berat segar brangkasan tanaman perhektar sebesar 19,02 ton/ha.

\section{UCAPAN TERIMAKASIH}

Pada kesempatan ini penulis ingin mengucapkan terimakasih yang sebesarbesarnya kepada orang tua dan seluruh keluarga, lembaga pendidikan Universitas Flores, dan seluruh pihak yang telah membantu kelancaran jalannya penelitian.

\section{DAFTAR PUSTAKA}

Adijaya. 2006. Pemanfaatan Biourine dalam Produksi Hijauan Pakan Ternak (Rumput Raja). Prosiding Seminar Nasional Dukungan Inovasi Teknologi dan Kelembagaan dalam Mewujudkan Agribisnis Industrial Pedesaan. Mataram, 22-23 Juli 2007. Balai Besar Pengkajian dan Pengembangan Teknologi Pertanian. Hal. 155-157.

BPS. 2014. Produksi Sawi Dalam Negeri. Badan Statistik Kabupaten Ende. 
Neno: Pengaruh pemberian dosis pupuk biourin terhadap pertumbuhan dan hasil tanaman padi

Cahyono, 2000. Teknik Budidaya dan Analisis Usaha Sawi Putih. CV Aneka Ilmu: Semarang.

Dinas Pertanian.2014. Produksi Sawi Nasional. Derektorat Jendral Hortikultural

Gardner, F.P., R. brent pearce and R.L. Mitchell. 2008. Fisiologi Tanaman Budidaya. Penerjemah: H. Susilo, UI Press, Jakarta. 247-261, 355368.

Gomez dan Gomez, 1995. Prosedur Statistik Untuk Penelitian Pertanian. Derektorat Jenderal Pendidikan Tinggi Depertemen Pendidikan dan Kebudayaan, Jakarta.

Hanafiah, K.A, 2007. Dasar-dasar Ilmu Tanah. Jakarta: PT. Raja Grafindo Persada.

Harjadi, M.S. 1993. Pengantar Agronomi. Gramedia Pustaka Utama. Jakarta.

Hardjowigeno, S. 2003 . Ilmu Tanah. Mediyatama Sarana Perkasa, Jakarta.
Islami, T. dan Utomo, W. H. 2011.

Hubungan Tanah, Air dan Tanaman. IKIP Semarang Press, Semarang.

Jumin H.B., 2008. Dasar-Dasar Agronomi, Pt. Radja Grafindo. Jakarta

Lingga. 1991. Kandungan Hara Dari Ternak. www.Geogle.Om. Weblog Older (8 Juli 2013).

Phrimantoro.1995. Urine Sapi Bangkitkan Harapan Petani. Bogor.

Rizky Karya, Rasyad Aslim, dan Murniati. 2014. Pengaruh Pemberian Urin Sapi Yang Difermentasi Terhadap Pertumbuhan Dan Produksi Tanaman Sawi Hijau (Brassica rafa). Jom Faperta Vol.1 No.2.

Sutari. 2010. Pupuk Bio Urine Aplikasi dan Manfaatnya. Agromedia Pustaka. Jakarta.Hal 111. 